\title{
Economic analyses of options for weedy Sporobolus grass management
}

\author{
Steven Bray ${ }^{\mathrm{A}, \mathrm{C}}$, Bill Holmes ${ }^{\mathrm{A}}$ and David Officer ${ }^{\mathrm{B}}$ \\ ADepartment of Primary Industries and Fisheries, Queensland, PO Box 6014, Rockhampton MC, \\ Qld 4702, Australia. \\ ${ }^{B}$ Department of Primary Industries, Private Mail Bag 2, Grafton, NSW 2460, Australia. \\ ${ }^{\mathrm{C}}$ Corresponding author. Email: steven.bray@dpi.qld.gov.au
}

\begin{abstract}
Weedy Sporobolus grasses have low palatability for livestock, with infestations reducing land condition and pastoral productivity. Control and containment options are available, but the cost of weed control is high relative to the extra return from livestock, thus, limiting private investment.

This paper outlines a process for analysing the economic consequences of alternative management options for weedy Sporobolus grasses. This process is applicable to other weeds and other pastoral degradation or development issues.

Using a case study property, three scenarios were developed. Each scenario compared two alternative management options and was analysed using discounted cash flow analysis. Two of the scenarios were based on infested properties and one scenario was based on a currently uninfested property but highly likely to become infested without active containment measures preventing weed seed transport and seedling establishment.

The analysis highlighted why particular weedy Sporobolus grass management options may not be financially feasible for the landholder with the infestation. However, at the regional scale, the management options may be highly worthwhile due to a reduction in weed seed movement and new weed invasions. Therefore, to encourage investment by landholders in weedy Sporobolus grass management the investment of public money on behalf of landholders with non-infested properties should be considered.
\end{abstract}

Additional keywords: livestock carrying capacity, natural resource management, public funding, weed management.

\section{Introduction}

The leaf blades of weedy Sporobolus grasses have low palatability to livestock relative to other pasture species. As the density of weedy Sporobolus grass increases, land condition and livestock carrying capacity decline due to the displacement of palatable and productive pasture species. Farmers have indicated that losses in carrying capacity and production range from 10 to $80 \%$ depending on the density of infestations (NRM 2001). If livestock numbers are not reduced in proportion to the amount of palatable forage, growth per animal declines due to limitations on forage intake and quality (NRM 2001).

Weedy Sporobolus grass encompasses five closely related species. Scenarios in this paper are based on giant rats tail grass (Sporobolus pyramidalis P. Beauv) and giant parramatta grass (Sporobolus fertilis Steud.), which infest significant areas of pasture from the south coast of New South Wales to north Queensland. The lifecycle of these weedy Sporobolus grasses are well adapted to invasion and dominance of grazed pastures (Andrews 1995; Andrews et al. 1996; Vogler 2002; Bray 2004; Bray and Officer 2007).

Various management interventions are available depending on land type and infestation density (Bray and Officer 2007). These interventions manipulate the level of weedy Sporobolus grass in a pasture and, therefore, change the productive pasture potential. However, the costs of these interventions are generally high, relative to the return from livestock. Hence, there is a need to determine what is economically possible for the landholder and whether 'external support' may be required to stimulate appropriate weedy Sporobolus grass management. External support may be relevant not only to the landholder with the weedy Sporobolus grass but also neighbouring and downstream properties.

\section{The approach}

A hypothetical case study property is generated (e.g. Fig. 1) where weedy Sporobolus grasses are currently or potentially a major issue. The property is designed to be a 'typical' commercial cattle property in size, land types, paddock number and livestock carrying capacity for the region.

Our hypothetical property 'Brig Plains' was generated for the central Queensland brigalow belt (Fig. 1). The property is 5390 ha and has a livestock carrying capacity of 1800 adult equivalents (AE) when in good condition ( $1 \mathrm{AE}=455 \mathrm{~kg}$ dry cow). The property is divided into eight paddocks and two land types. Seven of the paddocks are brigalow-blackbutt country (range in size from 550 to 850 ha with a smaller paddock of 90 ha Table 1) and one large paddock (1200 ha) of ironbark forest country. The enterprise breeds weaners, which are grown through 


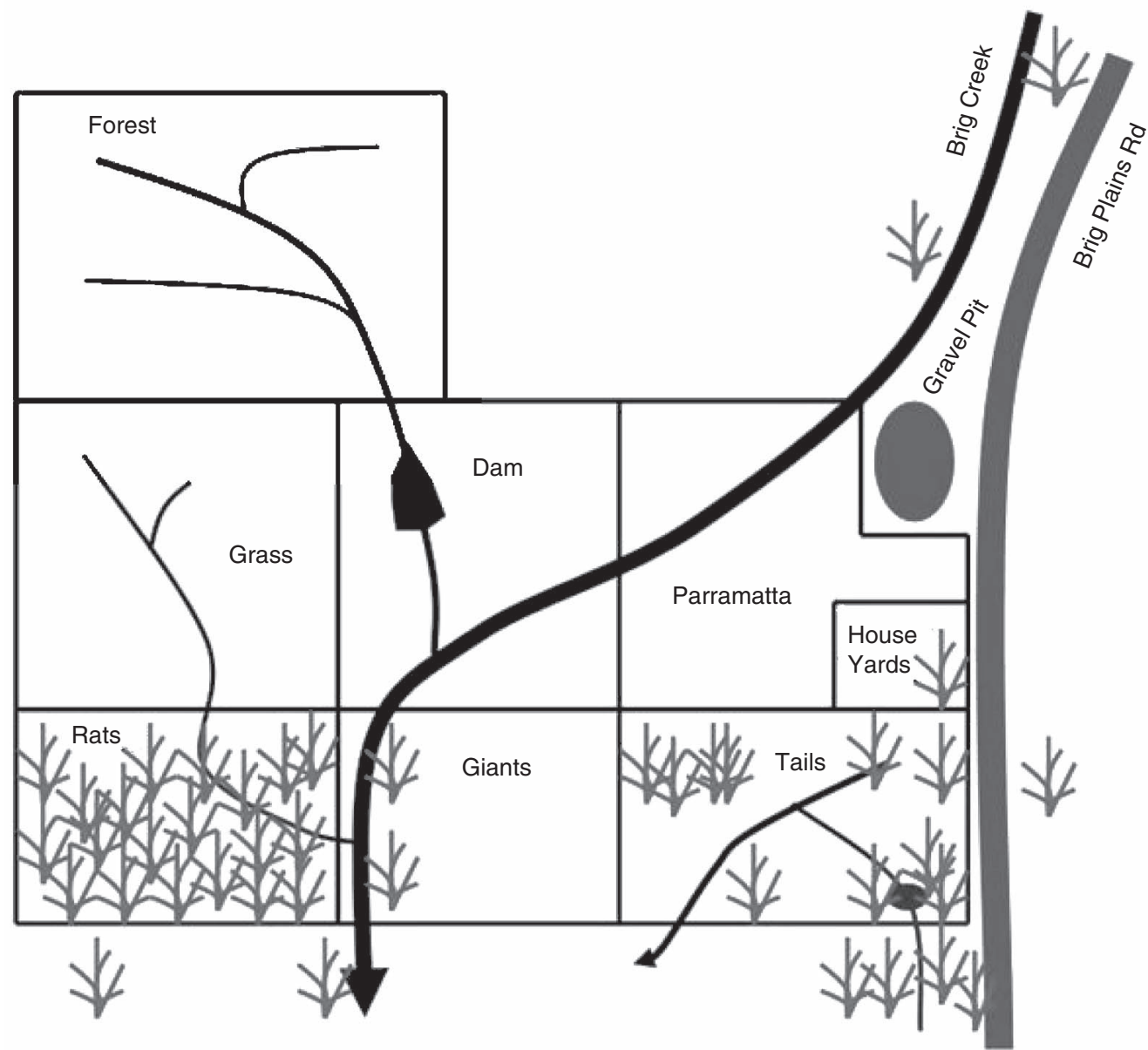

Fig. 1. Map of hypothetical case study property 'Brig Plains'. The stylised plants represent weedy Sporobolus grass infestation.

to bullocks. One paddock is densely infested with weedy Sporobolus grasses (Rats paddock - Fig. 1), one paddock (Tails) has weed clumps and scattered plants, two paddocks (Giants and House) have widely scattered weed plants. The other paddocks are not infested.

To assess the economic consequences of various weed management options, we developed scenarios that compared two different future paths (options). For example in Scenario 1, we compare the expected change over the next 50 years with no weed management ('do nothing'), relative to an alternative 'future', in this case, the broadacre herbicide control strategy. Both options within a scenario start with the same initial (Year 0) situation (e.g. level of infestation) and the different management options begin the following year (Year 1).

The 'STOCKTAKE' livestock carrying capacity calculator (DPI 2004) was used to calculate the number of livestock (AEs) that can be carried at various levels of weedy Sporobolus grass infestation in each paddock. The calculator reduced livestock carrying capacity based on four infestation conditions (Clean, Scattered, Clump or Dense; Table 2). Property livestock carrying capacity was modified during the fifty-year scenarios depending on the expected change in weedy Sporobolus grass infestation density in each paddock based on pre-determined rules and assumptions (discussed below).

The gross margin (GM) per AE was estimated for the case study property using Breedcow and Dynama software (Holmes 2005). The GM per AE will vary depending on the type of country, animal growth rate, branding rate, type of animals, husbandry costs and sale prices. As mentioned above, livestock carrying capacity will change with the level of weedy Sporobolus grass infestation but individual animal growth rates may also be affected (NRM 2001). The analyses were based on changes in livestock carrying capacity with changes in weed infestation. The GM per AE was not modified based on the density of an infestation as the stocking rates were matched to available palatable forage, therefore changes in AE productivity should be minimised.

An Excel spreadsheet was used to perform discounted cash flow (DCF) analysis on the various scenarios, in each instance comparing a weed control option with 'do nothing' (no weed management) and basing the DCF on the difference in cash flows.

Cash flow from livestock each year was calculated as underlying gross margin (calculated on a stable herd), minus or 
Table 1. Parameter values used in the analyses

\begin{tabular}{lc}
\hline Parameter & Unit values \\
\hline Gross margin per adult equivalent & $\$ 205$ \\
Capital value of one adult equivalent & $\$ 600$ \\
Interest rate for discounting & $6 \%$ \\
Land value/adult equivalent & $\$ 1500$ \\
Broadacre herbicide application cost & $\$ 85 / \mathrm{ha}$ \\
Containment costs for infested properties. Spot & $\$ 20000$ in year 1 \\
$\quad$ spray (limited by landholder time), & and $\$ 10$ 000 \\
quarantine (cattle) and containment costs & per year thereafter \\
(e.g. wash down facilities, buffer strips, & \\
vehicle track control) & \\
Preventing invasion costs for clean properties. & $\$ 10000$ in year 1 \\
Quarantine (cattle), property inspection & and $\$ 5000$ per year \\
(riparian areas, fencelines), wash down & thereafter \\
facilities & \\
Property size total & $5390 \mathrm{ha}$ \\
Tails paddock & $650 \mathrm{ha}$ \\
Grass paddock & $850 \mathrm{ha}$ \\
Parramatta paddock & $700 \mathrm{ha}$ \\
Dam paddock & $750 \mathrm{ha}$ \\
Forest paddock & $1200 \mathrm{ha}$ \\
House paddock & $90 \mathrm{ha}$ \\
Giants paddock & $550 \mathrm{ha}$ \\
Rats paddock & $600 \mathrm{ha}$ \\
&
\end{tabular}

Table 2. Infestation condition description for weedy Sporobolus grass infestations and the relative carrying capacity value

\begin{tabular}{|c|c|c|}
\hline $\begin{array}{l}\text { Condition } \\
\text { class }\end{array}$ & Description & $\begin{array}{l}\text { Proportion } \\
\text { of potential } \\
\text { carrying } \\
\text { capacity }\end{array}$ \\
\hline Clean & $\begin{array}{l}\text { No weedy Sporobolus grass present. Viable } \\
\text { weed seed needs to enter the pasture } \\
\text { followed by germination and weed } \\
\text { establishment before progression to } \\
\text { 'Scattered' condition. To transfer from } \\
\text { 'Scattered' to 'Clean' condition, all weed } \\
\text { plants and soil seed bank have to be } \\
\text { eliminated }\end{array}$ & 1 \\
\hline Scattered & $\begin{array}{l}\text { Initial invasion, scattered weedy Sporobolus } \\
\text { grass plants, little impact on carrying } \\
\text { capacity, but inevitable increase to 'Clump' } \\
\text { condition without management } \\
\text { intervention. Potential for spot-spray } \\
\text { control }\end{array}$ & 0.95 \\
\hline Clump & $\begin{array}{l}\text { Weedy Sporobolus grass clumps and plants } \\
\text { across the paddock. Moderate impact on } \\
\text { carrying capacity and inevitable increase to } \\
\text { 'Dense' condition without management } \\
\text { intervention }\end{array}$ & 0.8 \\
\hline Dense & $\begin{array}{l}\text { Dense weedy Sporobolus grass across the } \\
\text { paddock. Substantial impact on carrying } \\
\text { capacity. Major management intervention } \\
\text { required to reduce weed density }\end{array}$ & 0.4 \\
\hline
\end{tabular}

plus the value of transactions required to increase or decrease stock numbers from year to year to match livestock carrying capacity. Both the gross margin (\$205/AE) and the transaction value (\$600/AE), were standardised and the same values used for the whole term of the analysis. In making these estimates, the AE standard used was a non-lactating animal of average weight $455 \mathrm{~kg}$, carried for 12 months. Breeders were rated on the same weight basis plus $0.35 \mathrm{AE}$ for each breeder weaning a calf.

Annual weed management costs year by year were included in the cash flow.

The analysis period used was 50 years. A shorter period could have been used, but the longer the analysis period adopted, the less significant will be any errors in assigning end-of-analysis salvage values. Salvage values are assigned as a proxy for continuing the analysis in perpetuity. In this analysis salvage value at the end of the 50-year analysis was taken to comprise the value of additional cattle on hand relative to 'do nothing', and the value of additional carrying capacity as a result of weed control (due to land being in better condition), again relative to 'do nothing'.

The value of additional carrying capacity at year 50 was estimated as the value of annual gross margins accruing beyond 50 years, less the costs of maintaining that level of carrying capacity, discounted back to year 50. If these future benefits continue into perpetuity, the 50-year value of net benefits after year 50 will be the annual net value of utilised increased carrying capacity (extra AE times GM/AE less ongoing weed control costs), all divided by the interest rate.

Economic indices calculated in the analysis were net present value (NPV), annualised return (AR), internal rate of return (IRR), payback period and peak deficit.

NPV is the sum of the discounted (present) values of future annual cash surpluses and deficits, including the year 50 'salvage value'. NPV is a measure of profit from the investment, and is considered the appropriate measure for ranking options, assuming that all options are fundable.

The AR is equivalent to the NPV amortised over the 50-year analysis. AR is an alternate expression of investment profit to which grazing business managers may relate more easily.

The IRR is the interest rate at which NPV would be zero, i.e. the interest rate which if charged would make the project break even. The IRR is effectively the calculated rate of return on the project - in this case extra return on extra investment relative to 'do nothing'.

Payback period and peak deficit are derived from the cumulative cash flow. The cumulative cash flow comprises the accumulating total of annual cash flows, negative and positive, with compound interest. For the weed control scenarios examined, this cumulative cash flow is at first a deficit which increases year by year until the annual benefits come to exceed the interest cost, at which point the deficit begins to diminish and eventually turns into a surplus. Payback period is the number of years until cumulative cash flow, including compound interest becomes positive. The peak (maximum) deficit is one measure of the amount of finance required for the project. The peak deficit and payback period are not measures of investment efficiency as NPV and IRR are, but they may influence the funding of an investment.

An interest rate of $6 \%$ was chosen as representing a 'real' rate of interest appropriate to a social or community view of the project opportunities. Estimates of future costs and benefits were at 
current values with no allowance for inflation. For an individual investor, a higher interest rate, equivalent to 'opportunity cost', would be more appropriate. A higher rate of interest will reduce NPV, but will leave IRR unaffected, since IRR represents the breakeven interest rate between positive and negative NPV. As a test of decision making in the face of higher interest rates, the analysis was also performed for a $10 \%$ real interest rate. Assuming capital is available for any of the weed control options, but that the options are indivisible and mutually exclusive, the appropriate measure of investment ranking is NPV, calculated in the first instance at a rate appropriate to a community assessment of the project (in which case the benefits are underestimated since we should really include the social benefits not captured by the investor, which we have not measured), and at a rate appropriate to the grazier investor (opportunity cost).

\section{The analysis}

This paper reports on the analysis of three scenarios. Two scenarios compare two different weed management options against the same 'no weed management' (do nothing) option based on the infested case study property described above (Fig. 1). The third scenario uses the same case study property but assumes it is not initially infested and compares the option of applying strategies that prevent or contain weed invasion, against the option of no weed management resulting in eventual infestation of the property. Parameters used in the analyses are listed in Table 1.

\section{Scenario 1 - broadacre herbicide control strategy v. no weed management}

The option of applying the broadacre herbicide control strategy and containment strategies was compared to the option of conducting no weed management.

In the broadacre herbicide control strategy option, both Rats and Tails paddocks (Fig. 1) are sprayed with a broadacre selective herbicide (flupropanate) in Year 1 and Year 3 substantially reducing annual cash flow (Fig. 2). Rats paddock has another broadacre application in Year 14. Giants and House paddocks are spot-sprayed as are Rats and Tails paddocks following the second

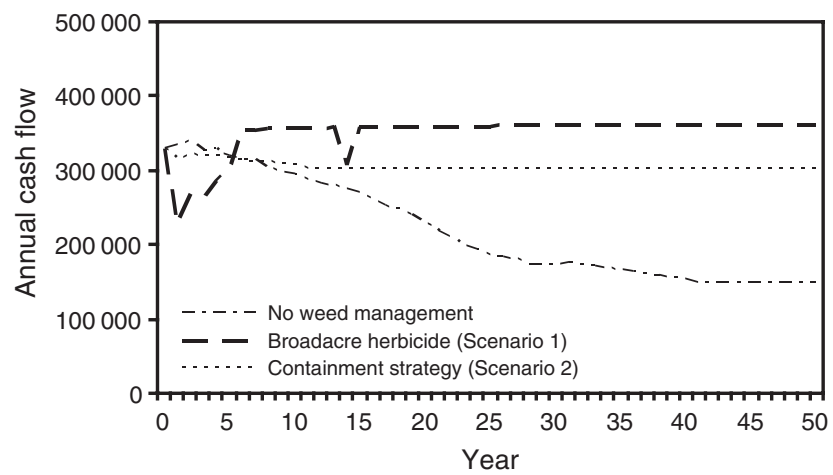

Fig. 2. Annual cash flow for the broadacre herbicide control strategy (Scenario 1) and the containment strategy (Scenario 2) relative to no weed management. broadacre herbicide application to control missed and newly established plants. Quarantine and weed seed movement containment measures are also established. The rules and assumptions for the option are detailed in Table 3 .

The no weed management option steadily increases in density of weedy Sporobolus grasses. The rules and assumptions for this option are detailed in Table 4.

Financial analysis at $6 \%$ interest (values for $10 \%$ interest in brackets) for the broadacre herbicide control option relative to no weed management option indicates an NPV of $\$ 1.259 \mathrm{~m}$ (\$0.340 m), an annualised return of \$79 865 (\$34313), an IRR of $16.0 \%$, a peak deficit of $\$ 362260$ (\$403 325) and a payback period of 13 (16) years (Table 5; Fig. 3). A substantial decline in livestock carrying capacity occurs with no weed management over time (Fig. 4).

This analysis does not include the benefits to neighbouring non-infested landholders from the removal of a weed seed source. Infested landholders may be deterred from this investment by the relatively large peak deficit or the relatively

Table 3. Rules and assumptions for change in weedy Sporobolus grass density when applying the broadacre herbicide control strategy (Scenario 1)

\begin{tabular}{l} 
Rule or assumption \\
\hline Pasture condition \\
Carrying capacity \\
in year of herbicide \\
application \\
Carrying capacity \\
in year following \\
herbicide \\
application \\
Livestock destocking \\
rules when applying \\
broadacre herbicide
\end{tabular}

Broadacre herbicide control of Clump condition paddocks

Broadacre herbicide control of Dense condition paddocks

\section{Details}

Assume good pasture species are across the infested paddocks which can replace killed weedy Sporobolus grasses

In the year of broadacre herbicide application, livestock carrying capacity is $50 \%$ of previous year due to the herbicide withholding period and to enable pasture recovery

In the year following broadacre application livestock carrying capacity is $80 \%$ of Scattered condition to enable pasture recovery

Clean condition paddocks are able to carry up to $10 \%$ higher stock numbers for two years in ten years, enabling the destocking of sprayed paddocks to be mitigated. Excess livestock are sold

Two herbicide applications are applied two years apart. Clump condition paddocks become Scattered condition in the second year following the herbicide applications and can progress to Clean condition with spot-spraying over the following 10 years

Two herbicide applications are applied two years apart, followed by a third application ten years later (Year 14) to control widely scattered plants not controlled with spot-spraying (important in extensive paddocks). Dense condition paddocks (substantial soil seed bank) become equivalent to Scattered condition in the second year following the first two herbicide applications and require spot-spraying to maintain Scattered condition. Following the third herbicide application the paddock can progress to Clean condition over the next 10 years with spot spraying 
Table 4. Rules and assumptions for change in weedy Sporobolus grass density with no weed management (Scenarios 1, 2 and 3)

\begin{tabular}{|c|c|}
\hline Rule or assumption & Details \\
\hline $\begin{array}{l}\text { Manipulating } \\
\text { infestation } \\
\text { levels between } \\
\text { Scattered, } \\
\text { Clump and } \\
\text { Dense condition }\end{array}$ & $\begin{array}{l}\text { Once a paddock is infested (e.g. Scattered } \\
\text { condition) it takes } 10 \text { years to drop down an } \\
\text { infestation level e.g. Scattered to Clump, or } \\
\text { Clump to Dense. Adult equivalent numbers } \\
\text { decline evenly over the } 10 \text { year period (e.g. } 5 \mathrm{AE} \\
\text { reduction per year, to drop } 50 \text { AEs changing } \\
\text { from Clump to Dense condition) }\end{array}$ \\
\hline $\begin{array}{l}\text { Infestation rule for } \\
\text { Clean condition } \\
\text { paddocks }\end{array}$ & $\begin{array}{l}\text { All Clean condition paddocks become infested } \\
\text { over a } 10 \text { year period (i.e. go from Clean to } \\
\text { Scattered condition). The year in which a } \\
\text { particular paddock becomes infested (Scattered } \\
\text { condition) is spread evenly over the } 10 \text { year } \\
\text { period (e.g. } 1 \text { of the four uninfested paddocks } \\
\text { becomes infested every } 2-3 \text { years) }\end{array}$ \\
\hline
\end{tabular}

Table 5. Economic indices for comparison of weedy Sporobolus grass management scenarios at two interest rates $6 \%$ and $10 \%$ (in parentheses)

\begin{tabular}{lccc}
\hline $\begin{array}{l}\text { Economic } \\
\text { indices }\end{array}$ & $\begin{array}{c}\text { Scenario 1 } \\
\text { Broadacre } \\
\text { herbicide } \\
\text { control strategy } v . \\
\text { no weed } \\
\text { management }\end{array}$ & $\begin{array}{c}\text { Scenario 2 } \\
\text { Containment } \\
\text { strategy } v \\
\text { no weed } \\
\text { management }\end{array}$ & $\begin{array}{c}\text { Scenario 3 } \\
\text { Preventing } \\
\text { invasion } \\
\text { strategy for } \\
\text { a clean } \\
\text { property } v . \\
\text { no weed } \\
\text { management }\end{array}$ \\
\hline Total NPV & $\$ 1258827$ & $\$ 813215$ & $\$ 1372279$ \\
Annualised & $(\$ 340208)$ & $(\$ 227628)$ & $(\$ 450054)$ \\
return & $\$ 79865$ & $\$ 51594$ & $\$ 87063$ \\
IRR & $(\$ 34313)$ & $(\$ 22958)$ & $(\$ 45392)$ \\
Payback & $16.0 \%$ & $19.7 \%$ & $31.2 \%$ \\
period (years) & $(16.0 \%)$ & $(19.7 \%)$ & $(31.2 \%)$ \\
Peak deficit & $13(16)$ & $13(15)$ & $8(9)$ \\
& $\$ 362260$ & $\$ 84599$ & $\$ 43035$ \\
& $(\$ 403325)$ & $(\$ 104431)$ & $(\$ 48364)$ \\
\hline
\end{tabular}

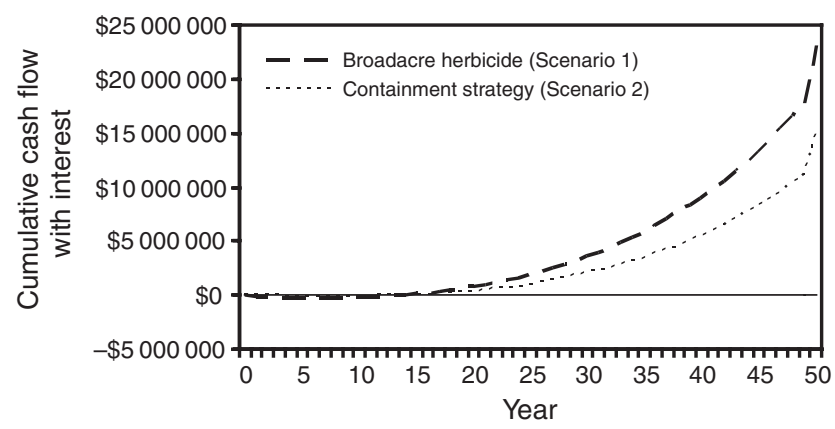

Fig. 3. Cumulative cash flow with interest including sale or purchase of livestock and salvage value at end of analysis for the broadacre herbicide control strategy (Scenario 1) and the containment strategy (Scenario 2) relative to no weed management.

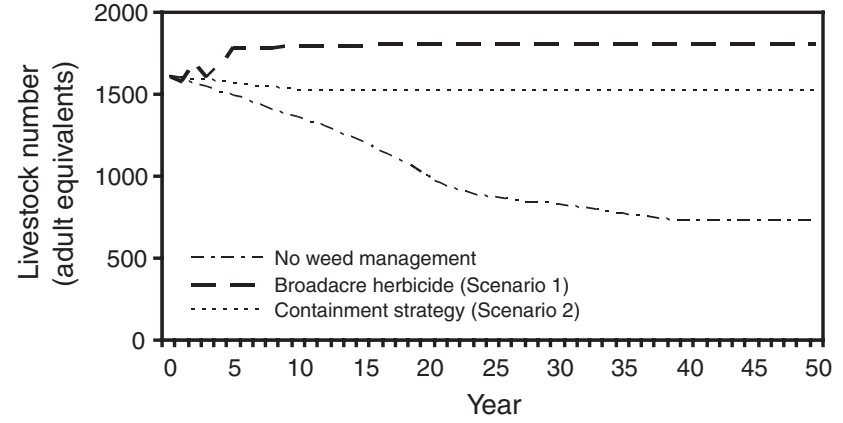

Fig. 4. Comparison of livestock numbers (adult equivalents) for the broadacre herbicide control strategy (Scenario 1) and the containment strategy (Scenario 2) relative to no weed management.

long payback period. There are, however, additional spillover benefits to non-infested landholders for which they do not currently pay. This infers a justification for non-infested landholders (or government acting on their behalf) to contribute to weed control costs on infested properties to protect productivity and land values of the so-far non-infested properties.

\section{Scenario 2 - containing spread on an infested property v.} no weed management

The option of containing the spread of weedy Sporobolus grasses was compared to the option of conducting no weed management. This scenario utilises the same case study property as Scenario 1 (Fig. 1). The no weed management option is the same as that used in Scenario 1 (Table 4).

Containment strategies (e.g. livestock quarantine, wash down facilities, buffer strips) cost $\$ 10000$ each year. In year 1 , an additional $\$ 10000$ is required (total $\$ 20000$ ) to control the weedy Sporobolus grass in the riparian areas in the infested Rats and Tail paddocks and in the Scattered condition paddocks (Table 6).

Table 6. Rules and assumptions for change in weedy Sporobolus grass density when containment strategies are applied (Scenario 2)

\begin{tabular}{|c|c|}
\hline Rule or assumption & Details \\
\hline $\begin{array}{l}\text { Weed seed spread to } \\
\text { clean paddocks can } \\
\text { be contained }\end{array}$ & $\begin{array}{l}\text { Implementing a package of buffer strips, } \\
\text { quarantine paddocks, wash down areas, } \\
\text { vehicle and livestock movement } \\
\text { controls and weed control in riparian } \\
\text { areas will stop the spread of the weed to } \\
\text { Clean paddocks }\end{array}$ \\
\hline $\begin{array}{l}\text { Clump and Dense } \\
\text { condition paddocks }\end{array}$ & $\begin{array}{l}\text { Clump condition paddocks will progress to } \\
\text { Dense condition over } 10 \text { years and } \\
\text { Dense condition paddocks will remain } \\
\text { Dense condition. Weed control is } \\
\text { conducted in riparian areas in Clump } \\
\text { and Dense condition paddocks }\end{array}$ \\
\hline $\begin{array}{l}\text { Scattered condition } \\
\text { paddocks }\end{array}$ & $\begin{array}{l}\text { Scattered condition paddocks can become } \\
\text { Clean condition with concerted spot- } \\
\text { spraying over } 10 \text { years }\end{array}$ \\
\hline
\end{tabular}


The predicted NPV over 50 years for containing the spread of weedy Sporobolus grasses $v$. no weed management at $6 \%$ interest (figures for $10 \%$ interest in brackets) was $\$ 0.813 \mathrm{~m}$ (\$0.228 m), with an annualised return of \$51 594 (\$22 958), an IRR of $19.7 \%$, a peak deficit of $\$ 84599$ (\$104431) and a payback period of 13 (15) years (Table 5; Fig. 3). Livestock carrying capacity remains relatively stable by containing weed spread compared to a substantial decline with no weed management (Fig. 4).

This analysis does not include the benefits to neighbouring non-infested landholders from the containment of a weed seed source. One negative aspect of the containment of spread option is that although the infestation is reasonably contained, it is still a potential source of seed contamination for clean areas on the property and other properties (e.g. downstream), particularly during major flood events, feral animal movement or if containment strategies are not maintained.

\section{Scenario 3 - preventing invasion of a clean property v. no weed management}

The preventing invasion scenario assumes the case study property was initially not infested with weedy Sporobolus grass and therefore the case study property differs from the other two scenarios. However, infestations are nearby (e.g. the neighbours, upstream, purchased cattle of unknown history) and therefore the property is highly likely to be infested. This scenario tests the option of investing in strategies to prevent or contain weed invasion $v$. the option of no weed management. The prevention of weed invasion option maintains the paddocks in Clean condition throughout the scenario with a $\$ 10000$ cost in year 1 to establish strategies to prevent weed invasion (e.g. wash down facilities, livestock quarantine) with an annual cost of $\$ 5000$ per year thereafter. The no weed management option follows the rules and assumptions in Table 4.

The predicted NPV over 50 years for prevention of invasion of weedy Sporobolus grasses at 6\% interest (figures for 10\% interest in brackets), was $\$ 1.372 \mathrm{~m}(\$ 0.450 \mathrm{~m})$, with an annualised return of $\$ 87063$ (\$45392), an IRR of $31.2 \%$, a peak deficit of $\$ 43035$ (\$44 121) and a payback period of 8(9) years (Table 5). A substantial decline in livestock carrying capacity occurs with no weed management over time (Fig. 5).

The preventing invasion strategy is clearly the best based on the economic indices, as it has the highest NPV and annualised return (at both interest rates), the highest IRR, the least required

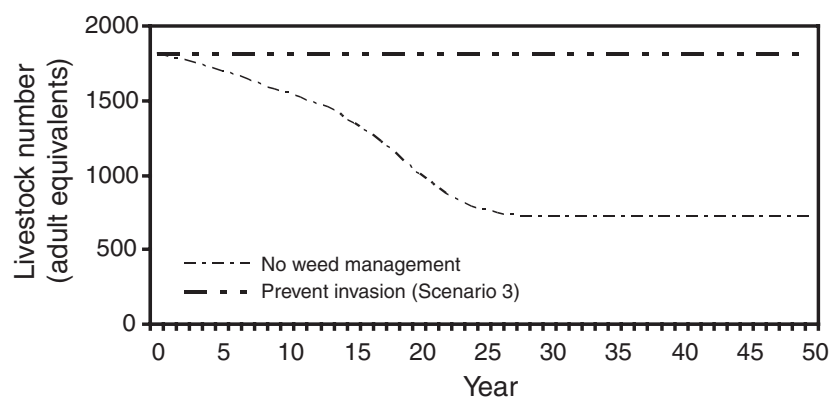

Fig. 5. Comparison of livestock numbers (adult equivalents) for the invasion prevention strategy (Scenario 3) relative to no weed management. capital, and the shortest payback period of the strategies analysed. This option appears worthwhile for landholders who are currently not infested with weedy Sporobolus grass but are likely to become infested over time. This analysis prescribes some containment strategies in which to invest (e.g. wash down facilities, livestock quarantine), however, some of the investment may be better spent off-property controlling a potential seed source (e.g. an infestation on a neighbours property upstream or a buffer strip inside the neighbours fence). The positive aspect of the preventing invasion strategy is that weed invasion is prevented for a minor investment relative to the substantial financial and productivity penalty of having to manage weedy Sporobolus grass infested pastures.

\section{Considerations for selecting a management strategy}

If the preventing invasion strategy was not available, perhaps because the infestation has escaped, the choice would come down to one of the first two strategies (broadacre herbicide and containing spread). NPV alone indicates preference for the broadacre herbicide strategy, though this strategy requires four times the investment of the containing spread strategy. IRR indicates a higher percentage return (on the smaller capital requirement) for the containing spread strategy. The question then becomes whether it is worth putting in the extra capital (nearly $\$ 280000$ extra peak deficit at $6 \%$ or $\$ 300000$ at $10 \%$ ) to get the extra return.

Discounted cash flow analysis of the cash flow differences between the broadacre herbicide and containing spread strategies indicate a return on additional investment of $13.8 \%$ by shifting from the second to the first strategy. If $13.8 \%$ is above the opportunity cost of the investor, then the broadacre herbicide strategy would be preferred over the containing spread strategy. Marginal NPV of the broadacre herbicide strategy over the containing spread strategy, calculated from the difference in cash flows, is $\$ 445612$ at $6 \%$.

\section{Implications for natural resource management agencies}

Preventing invasion (Scenario 3) is clearly the best investment option of the three examined, with the best overall NPV at both interest rates. The preventing invasion strategy should be highly encouraged across regions, not only for weedy Sporobolus grass management but also for the management of other weeds. Only at an interest rate close to zero does the broadacre herbicide strategy (Scenario 1) produce an NPV approximately equal to that of the preventing invasion strategy.

Comparing the broadacre herbicide and the containing spread strategies on infested properties, the broadacre herbicide strategy would be considered the best investment since it produces the highest NPV, however, it does require approximately four times the investment of the containing spread strategy, and notwithstanding the favourable marginal return (IRR 13.8\%) on moving up from the containing spread strategy to the broadacre herbicide strategy, the increased investment may be more difficult to finance. However, at the regional scale the broadacre herbicide strategy would be a worthy case for subsidisation relative to the containing spread strategy, since it eliminates the seed source rather than just suppressing the seed source with the ongoing risk of seed movement from the 'contained' infestations particularly 
during floods and uncontrolled feral and native animal movement.

The investment scenarios analysed also have a benefit for neighbouring landholders, and indeed for the region as a whole through reduced potential for weed seed spread. Had the regional benefits been included in the analysis, the NPV and IRR would be higher, perhaps much higher, particularly where a property is a seed source 'hot-spot' (e.g. at the head of a catchment). An indication of the regional benefits is provided by the preventing invasion strategy (Scenario 3), where the most efficient investment to prevent invasion may have been to help control the weed in the neighbours' riparian zone.

These analyses highlight the substantial financial cost of managing weedy Sporobolus grass infestations and suggest there is a case for a public financial contribution to infested landholders to 'sweeten' the investment in control strategies on behalf of other landholders who will benefit from weedy Sporobolus grass management on the infested properties.

\section{Acknowledgements}

We wish to thank the internal reviewers and referees for comments on the manuscript. Thank you to Meat and Livestock Australia (MLA) for financial support. This paper was presented at a Resource Economics Workshop, Rockhampton 2005 (www.agsip.cqu.edu.au/workshops/AGSIP2005.htm).

\section{References}

Andrews, T. S. (1995). The population biology of giant Sporobolus R.Br. species as an aid to their management in pastures on the North Coast of New South Wales. Ph.D. Thesis, University of New England, Armidale, NSW, Australia.

Andrews, T. S., Whalley, R. D. B., and Jones, C. E. (1996). Seed production and seedling emergence of giant Parramatta grass on the North Coast of New South Wales. Australian Journal of Experimental Agriculture 36, 299-308. doi: 10.1071/EA9960299

Bray, S., and Officer, D. (2007). 'Weedy Sporobolus Grasses Best Practice Manual.' (Department of Primary Industries and Fisheries, Queensland: Brisbane.)

Bray, S. G. (2004). The successful lifecycle of the pasture weed giant rats tail grass (Sporobolus pyramidalis). Ph.D. Thesis, School of Agronomy and Horticulture, The University of Queensland, Brisbane, Qld, Australia.

DPI (2004). 'Stocktake - Balancing Supply and Demand. QE04001.' (Department of Primary Industries and Fisheries, Queensland: Brisbane.)

Holmes, W. E. (2005). 'Breedcow and Dynama Herd Budgeting Software Package, Version 5.04. Training Series QE99002.' (Queensland Department of Primary Industries and Fisheries: Townsville.)

NRM (2001). 'Weedy Sporobolus Grasses Strategy 2001-2006.' (Natural Resources and Mines, Queensland.)

Vogler, W. D. (2002). Autecology of Sporobolus pyramidalis with emphasis on seed ecology. Ph.D. Thesis, School of Agronomy and Horticulture, The University of Queensland, Brisbane, Qld, Australia.

Manuscript received 5 October 2007; accepted 13 October 2008 